\title{
Effect of the circadian cycle in Late Asthmatic Response (LAR). Comparison between two allergic asthma models in rats and mice
}

\author{
Raquel Otal*, Sandra Muñoz, Elena Calama, Isabel Pagán, Félix Gil, Núria Torán, Montserrat Miralpeix, \\ Jorge De Alba
}

From 2nd Cross Company Respiratory Symposium

Horsham, UK. 6-7 September 2012

The ovalbumin (OVA) model of allergic inflammation, both in rat and mouse is characterised by a late bronchoconstrictive response (LAR) after allergen challenge that can be measured using whole-body plethysmography (WBP) in conscious unrestrained animals.

Circadian oscillations of lung mechanical properties have been reported in conscious undisturbed rodents. Potentially, these fluctuations could alter the pulmonary response induced by allergen provocation and the response of pharmacological treatments.

This circadian influence has been showed in asthma patients [1], where an allergen inhalation challenge given in the evening produced a more frequent and severe LAR compared to that one given in the morning.

The aim of this study was to assess whether LAR in OVA-sensitized rats and mice was affected differently when animals were exposed to allergen in different times of day.

Firstly, to confirm the circadian oscillations, changes in several respiratory parameters were monitored during 24h in naïve Brown Norway rats or C57/Black6 mice. Afterwards, OVA-sensitized animals were exposed to the allergen in different periods of the day and the pulmonary function parameters were monitored, including the LAR.

In rats, LAR evoked in three different times of day (morning, afternoon or evening) showed no differences in severity, but was more frequent during the evening. In contrast, the LAR triggered in mice in the morning was more severe and more frequent than that evoked during the evening.

\footnotetext{
* Correspondence: raquel.otal@almirall.com

Respiratory Therapeutic Area, Discovery, Almirall R\&D Centre, 08980 Barcelona, Spain
}

(c) 2013 Otal et al; licensee BioMed Central Ltd. This is an Open Access article distributed under the terms of the Creative Commons Attribution License (http://creativecommons.org/licenses/by/2.0), which permits unrestricted use, distribution, and reproduction in any medium, provided the original work is properly cited.
These results suggest that species and day period of time to induce LAR in allergic animal models are critical and should be taken into account when evaluating the effects of new compounds on this read-out.

Published: 14 August 2013

\section{Reference}

1. Mohiuddin AA, Martin RJ: Circadian basis of the late asthmatic response. Am Rev Respir Dis 1990, 142(5):1153-7.

doi:10.1186/1476-9255-10-S1-P13

Cite this article as: Otal et al:: Effect of the circadian cycle in Late Asthmatic Response (LAR). Comparison between two allergic asthma models in rats and mice. Journal of Inflammation 2013 10(Suppl 1):P13.

Submit your next manuscript to BioMed Central and take full advantage of:

- Convenient online submission

- Thorough peer review

- No space constraints or color figure charges

- Immediate publication on acceptance

- Inclusion in PubMed, CAS, Scopus and Google Scholar

- Research which is freely available for redistribution 